\title{
Ukrainian Studies in Canada Since the 1950s: An Introduction
}

\author{
Roman Senkus
}

Canadian Institute of Ukrainian Studies, Toronto Office, University of Alberta

$\mathrm{T}$ he field of Ukrainian Studies in Canada has had an illustrious history since the 1950s. Over the past seven decades, Canadian Ukrainianists have produced many monographs and other studies. Their contributions are discussed in detail in the survey articles. Here I shall but name the significant contributors (with apologies for any inadvertent omissions).

In the 1950s and 1960s they were the Canadian university professors Constantine H. Andrusyshen, Bohdan R. Bociurkiw, Dmytro Doroshenko, George S. N. Luckyj, Jaroslav B. Rudnyckyj, Yar Slavutych, and Paul Yuzyk. Alongside them, many of Canada's post-World War II Ukrainian émigré scholars made important contributions to Ukrainian church studies, history, and literary studies-Metropolitan Ilarion (Ohiienko), Fr. Iurii Fedoriv, Bohdan Kazymyra, Fr. Vasyl' Kudryk, Fr. Tymofii Minenko, Fr. Irenei Nazarko, Fr. Petro Romanyshyn, Fr. Meletii Solovii, Fr. Myron Stasiv, and Ivan Vlasovs'kyi/Wlasowsky.

In the late 1960s a few Ukrainianists trained in Canada and/or the United States became professors at Canadian universities-Roma Franko, Oleh W. Gerus, Jaroslav Rozumnyj, Roman Serbyn, and Danylo Husar Struk. In addition, in the early 1970s the renowned historian Ivan Lysiak Rudnytsky left La Salle College in Philadelphia for a professorship at the University of Alberta.

The creation of the Canadian Institute of Ukrainian Studies (CIUS) in 1976 marked the beginning of a new era in Ukrainian studies in Canada. At the University of Alberta, Manoly R. Lupul, the CIUS's first director (197686), initiated several projects: conferences in Ukrainian-Canadian studies, the Ukrainian Language Education Centre, and the writing of a multi-volume history of Ukrainians in Canada. At the CIUS Toronto Office, the CIUS's associate director (1976-82) - the eminent literary scholar George S. N. Luckyj-conceptualized and established the Encyclopedia of Ukraine project, the Journal of Ukrainian Studies, and a publishing program that in time evolved into the CIUS Press. At McMaster University, CIUS associate Peter J. Potichnyj organized the first Canadian conferences on UkrainianPolish, Ukrainian-Jewish, and Ukrainian-Russian relations; all of them were cosponsored by the CIUS. 
Over time other Ukrainian studies professorships and centres were established: the Chair of Ukrainian Studies at the University of Toronto (1979), the Centre for Ukrainian Canadian Studies (1981) at the University of Manitoba, the Peter Jacyk Centre for Ukrainian Historical Research (1989) at the CIUS, the Huculak Chair of Ukrainian Culture and Ethnography (1990) and the Kule Chair in Ukrainian Ethnography (2004) at the University of Alberta, the Prairie Centre for Ukrainian Heritage (1998) at the University of Saskatchewan, the Chair of Ukrainian Studies (2003) at the University of Ottawa, and more recently, the Kule Ukrainian Canadian Studies Centre at the CIUS, the Holodomor Research and Education Consortium at the CIUS Toronto Office, the Peter and Doris Kule Centre for Ukrainian and Canadian Folklore at the University of Alberta, and the Kule Chair at MacEwan University (Edmonton).

Today, Ukrainianists can be found at Canadian universities "from sea to sea"-in Victoria, Vancouver, Prince George, Edmonton, Saskatoon, Winnipeg, Sudbury, Windsor, London, Waterloo, Toronto, Kingston, Ottawa, Montreal, and St. John's.

Since the 1960s, many Canadian scholars have produced monographs and/or important studies in Ukrainian studies:

In archeology: Volodymyr Mezentsev.

In art history and criticism: the late Bohdan Stebel's'kyi, Daria Darewych, John-Paul Himka, the late Ivan Keivan, and Myroslav Shkandrij.

In church history: Anna Maria Baran, the late Fr. Oleksander/Alexander Baran, the late Fr. Petro Bilaniuk, the late Bohdan R. Bociurkiw, Heather Coleman, Daniel Galadza, Fr. Petro Galadza, Oleh W. Gerus, John-Paul Himka, Stella Hryniuk, the late Metropolitan Ilarion, the late Fr. Stephan Jarmus, Bohdan Kazymyra, Andrii Krawchuk, the late Fr. Orest Kupranets', the late Fr. Vasyl' Laba, Paul Laverdure, Fr. Athanasius McVay, the late Fr. Ihor Monchak/Mončak, Russell P. Moroziuk, the late Iurii Mulyk-Lutsyk, Bishop David Motiuk, the late Fr. Irenei Nazarko, Vivian Olender, Serhii Plokhy, the late Fr. Petro Romanyshyn, the late Fr. Meletii Solovii, the late Fr. Myron Stasiv, Frank E. Sysyn, Fr. Myroslaw Tataryn, the late Fr. Andrii Trukh, the late Hryhorii Udod, Roman Yereniuk, and the late Paul Yuzyk.

In economics: Oleh Havrylyshyn and the late Peter Woroby.

In ethnography and folklore: Roman Fodchuk, Robert B. Klymasz, Natalie Kononenko, Mariya Lesiv, Bohdan Medwidsky, Andriy Nahachewsky, and Natalia Khanenko-Friesen.

In film studies: Bohdan Nebesio.

In historical and political geography: Lubomyr Y. Luciuk and Ihor Stebelsky.

In history: Henry Abramson, Olga Andriewsky, the late Fr. Oleksander/Alexander Baran, Marko Bojcun, the late Jurij Borys, Serge Cipko, Fr. Martin Dimnik, Marta Dyczok, Oleh Gerus, John-Paul Himka, Stella Hryniuk, Ksenya Kiebuzinski, Bohdan Klid, Zenon E. Kohut, Volodymyr Kravchenko, Bohdan Krawchenko, Paul Robert Magocsi, David R. Marples, Victor 
Ostapchuk, Andrew Pernal, Serhii Plokhy, Peter J. Potichnyj, Thomas M. Prymak, the late Ivan Lysiak Rudnytsky, Roman Serbyn, the late Orest Subtelny, Frank E. Sysyn, Stephen Velychenko, the late Vasyl'/Wasyl Veryha, Serhy Yekelchyk, and Andriy Zayarnyuk.

In linguistics, lexicography, and grammar: the late Constantine $\mathrm{H}$. Andrusyshen, Terrence R. Carlton, Andrij Hornjatkevyč, the late Metropolitan Ilarion, Alla Nedashkivska, the late Vasyl' Nin'ovs'kyi, Mykola Pavliuk/Nicolae Pavliuc, the late Jaroslav B. Rudnyckyj, Yuri Shevchuk, the late Yar Slavutych, and the late Danylo Husar Struk.

In literature: Romana Bahry, the late Constantine Bida, Roma Franko, Halyna Hryn, Oleh S. Ilnytzkyj, Svitlana Kobets, the late Oleksandra Kopach, Taras Koznarsky, Svitlana Krys, the late George S. N. Luckyj, Irena Makaryk, Natalia Pylypiuk, Maria Rewakowicz, Maryna Romanets, the late Jaroslav Rozumnyj, Myroslav Shkandrij, Walter Smyrniw, Mykola Soroka, Marko Robert Stech, the late Danylo Husar Struk, and Maxim Tarnawsky.

In philosophy: the late Taras Zakydalsky.

In politics or political science: Dominique Arel, the late Bohdan R. Bociurkiw, Marko Bojcun, Marta Dyczok, Bohdan Harasymiw, Ivan (John) Jaworsky, Bohdan S. Kordan, Bohdan Krawchenko, Taras Kuzio, Lubomyr Y. Luciuk, David R. Marples, Mikhail Molchanov, Natalie Mychajlyszyn, Olga Onuch, and Peter J. Potichnyj.

In sociology: Wsevolod Isajiw and W. Roman Petryshyn.

In Ukrainian-Canadian studies: Jars Balan, Lisa Grekul, Rhonda L. Hinther, Stella Hryniuk, Bohdan S. Kordan, Vadim Kukushkin, Lindy Ledohowski, John C. Lehr, Lubomyr Y. Luciuk, Manoly R. Lupul, Andrij Makuch, Orest T. Martynowych, the late Mykhailo/Michael Marunchak, Jim Mochoruk, Peter Melnycky, Myron Momryk, Jaroslav Petryshyn, Thomas M. Prymak, Frances Swyripa, Roman Yereniuk, Paul Yuzyk, and Stacey Zembrzycki.

After Ukraine became independent, many students from Ukraine pursued graduate studies at Western universities. Among them, several Ukrainianists have become professors at Canadian universities-Natalia Khanenko-Friesen, Taras Koznarsky, Svitlana Krys, Mariya Lesiv, Mikhail Molchanov, Alla Nedashkivska, Maryna Romanets, Serhy Yekelchyk, Andriy Zayarnyuk. So has Volodymyr Kravchenko, a former professor at the Kharkiv National University, who served as director of the CIUS from 2012 to 2017.

At the same time, a few Canadian Ukrainianists have pursued careers and made scholarly contributions outside Canada. The historian and political scientist Bohdan Krawchenko, another former director of the CIUS (198691), became the founding director of the Institute of Public Administration and Local Government (Cabinet of Ministers of Ukraine, 1992-95) and vicerector of the Academy of Public Administration (Office of the President of Ukraine, 1995-2004) in Kyiv; he has been the director general of the University of Central Asia in Bishkek, Kyrgyz Republic, since 2004. Also, in Kyiv two former Torontonians, literary scholar Roman Weretelnyk and 
sociologist Mychailo Wynnyckyj, are professors at the National University of "Kyiv-Mohyla Academy."

In the United States, Serhii Plokhy, the Mykhailo Hrushevs'kyi Professor of History at Harvard University since 2007, was a professor of Ukrainian history at Dnipropetrovsk (now Dnipro) University before immigrating to Canada to become a CIUS research associate and deputy director of the Peter Jacyk Centre for Ukrainian Historical Research (1996-2007). Four former Torontonian Ukrainianists have pursued careers in the United States. Christine Worobec, a historian of Russia and Ukraine, was a professor at Kent State University (1984-99) and recently ended her career at Northern Illinois University as a distinguished research professor emerita. Literary scholar Halyna Hryn taught Ukrainian at Yale University and is the editor of Harvard Ukrainian Studies. Another specialist in Ukrainian literature, Marta Rewakowicz, taught Ukrainian at the University of Washington. The Ukrainian linguist and political scientist Yuri Shevchuk emigrated from Ukraine to Canada in the late 1990s and lived for a few years in Toronto before becoming the lecturer in the Ukrainian language at Columbia University and the founder of the Ukrainian Film Club there.

In England, another former Torontonian, historian, and political scientist, Marko Bojcun, has lived in London for over three decades. There he co-wrote one of the first books about the 1986 Chornobyl nuclear accident, taught the first Ukrainian history course at a British university (the University of London), and was a senior lecturer in politics at the University of North London and London Metropolitan University (and the director of its Ukraine Centre), and an adjunct professor at the London campus of New York University. Another Ukrainianist and former Torontonian, Olga Onuch, was appointed a lecturer in politics at the University of Manchester a few years ago.

$* * *$

In late December 2015, on the eve of CIUS's fortieth-anniversary year, CIUS's then director, Volodymyr Kravchenko, asked me to put together a special issue of EWJUS on Canadian contributions to Ukrainian studies during the seven decades that have passed since the end of World War II. In 2016 most of the dozen or so scholars I invited to write survey articles about their respective areas of Ukrainian studies accepted my invitation.

This issue begins with Zenon Kohut's report on CIUS activities and achievements during the two decades he was CIUS's longest-serving director, and contains five contributions in alphabetical order by surname: Bohdan Harasymiw on Soviet Ukraine studies, Andrij Hornjatkevyč on Ukrainian language and linguistic studies, Ivan (John) Jaworsky on post- 
Soviet Ukraine studies, Andriy Nahachewsky on studies of Ukrainian ethnography and folklore, and Serhy Yekelchyk on studies of Ukraine's modern history. A subsequent issue will contain Jaroslav Skira and Fr. Myroslaw Tataryn's article on Ukrainian church history and theological studies, my article on Ukrainian literary studies, and, I hope, at least two, if not three, articles about other fields.

I thank all of the authors for their co-operation and excellent contributions, Svitlana Krys for her readiness to publish the articles in $E W J U S$, and the entire EWJUS team for their editorial input. 